\title{
7. MINERALOGY OF SEDIMENTS FROM THE CHILE TRIPLE JUNCTION ${ }^{1}$
}

\author{
Viktor Kurnosov, ${ }^{2}$ Ivar Murdmaa, ${ }^{3}$ Nikolai Chamov, ${ }^{2}$ Oleg Chudaev, ${ }^{4}$ Vadim Eroshchev-Shak, ${ }^{2}$ and Lazar Shterenberg ${ }^{2}$
}

\begin{abstract}
Quaternary and Pliocene terrigenous sediments recovered during Ocean Drilling Program Leg 141 on the Chile Trench continental slope are represented by hemipelagic mud and distal and proximal turbidites with minor gravity-flow deposits. The coarse fraction is composed mainly of quartz and feldspars, with hornblende, epidote, and clinopyroxene dominating the heavy fraction. Volcanic glass, mica, orthopyroxene, tremolite-actinolite, olivine and "sialic" accessories (garnet, zircon, apatite, tourmaline, and sphene) occur in minor amounts. Clay minerals consist mainly of hydromica (illite) and chlorite, and smectite is a common minor component. The mineral assemblage found in the sediment sequences is derived from the adjacent Andean orogenic source area. Only the basal beds of the sedimentary blanket over the Taitao Ridge contains volcanic minerals possibly derived from local submarine outcrops of mafic igneous rock. Both the clay mineralogy and coarse-fraction mineralogy of the sediments are generally uniform, irrespective of the location of the holes on the accretionary wedge, of water depth, of depth below seafloor, of lithologic units, of tectonic deformation, or of lithification, and they do not change markedly with grain size or depositional style. The accretionary wedge terrigenous sediments are affected by hydrothermal alteration over the subducted Chile spreading ridge (Site 863). The hydrothermal effects are best demonstrated by extensive secondary smectite formation in the sediments. Subduction of the spreading ridge produces a "hydrothermal trace" in the accretionary wedge.
\end{abstract}

\section{INTRODUCTION}

Leg 141 of the Ocean Drilling Program (ODP) occupied five sites on the continental trench slope of the Chile Triple Junction between the Darwin and Taitao fracture zones. The Chile Triple Junction region is one of only two examples where an actively spreading mid-oceanic ridge is being subducted, an event that had occurred elsewhere along the convergent margins of the Pacific Ocean basin in the geological past. Spreading-ridge subduction events are likely to leave a distinctive structural and stratigraphic signature in the geological record of the overriding plate. Hydrothermal alteration, anomalous diagenesis, and mineralization of forearc materials driven by the hot fluids venting from the subducting spreading ridge can also be expected.

Major goals of our study are to investigate the mineralogy of the accreted and underthrusted sediment sequences and search for the hydrothermal alteration of sediments.

\section{SITES AND SETTINGS}

The three Sites 859,860 , and 861 were drilled in a transect across the continental trench slope at the Chile Triple Junction at water depths ranging from 2471 to $1652 \mathrm{~m}$ (Fig. 1) (Behrmann, Lewis, Musgrave, et al., 1992). At Site 859 on the lowermost trench slope, Hole $859 \mathrm{~A}$ penetrated to $146.5 \mathrm{~m}$ below seafloor (mbsf), and Hole $859 \mathrm{~B}$ to $476.1 \mathrm{mbsf}$. Drilling at Site 859 penetrated the toe region of an approximately $10-\mathrm{km}$-wide accretionary wedge at the leading edge of the South American forearc basement. The accretionary wedge is composed of a uniform suite of fine-grained terrigenous sediments of Pliocene age and is overlain by a thin, lower trench-slope hemipelagic cover sequence of Pleistocene and late Pliocene age.

The sediments recovered at Site 859 were divided into two units (Behrmann, Lewis, Musgrave, et al., 1992). Lithologic Unit I is composed of clayey silt and silty clay. From $10 \mathrm{~m}$ to $235 \mathrm{mbsf}$ is Subunit IIA of uniform clayey silts and silty clays. Lithologic Subunit

\footnotetext{
'Lewis, S.D., Behrmann, J.H., Musgrave, R.J., and Cande, S.C. (Eds.), 1995. Proc. $O D P_{3}$ Sci. Results, 141: College Station, TX (Ocean Drilling Program).

${ }^{2}$ Geological Institute, Pyzhevsky Per. 7. Moscow 109017, Russia.

${ }^{3}$ Institute of Oceanology, Krasikov St., 23, Moscow 117218, Russia

${ }^{4}$ Far East Geological Institute, Vladivostok 690022, Russia.
}

IIB (from 235 to $476 \mathrm{mbsf}$ ) consists of silty claystone and clayey siltstone, which were deposited at middle to lower bathyal depths.

Site 860 is the central site in the transect. It is located near the seaward side of a small forearc basin underlain by deformed and accreted forearc material and/or by autochthonous South American basement. Hole $860 \mathrm{~A}$ was drilled to $9.5 \mathrm{mbsf}$, and Hole $860 \mathrm{~B}$ to 617.8 mbsf. The ages of the sediments recovered range from late Pliocene to early Pliocene, overlain by $70 \mathrm{~m}$ of Quaternary hemipelagic sediment.

According to the shipboard description (Behrmann, Lewis, Musgrave, et al., 1992), the sediments recovered at Site 860 consist of clayey silt to silty clay and contain graded silt and sand interbeds (Unit I, 0-87.7 mbsf); claystone to silty claystone as well as sandstone and thin conglomerate beds (Unit II, 87.7-242.5 mbsf); clayey siltstone, silty claystone, and sandy silty claystone with thin conglomerate beds (Subunit IIIA, 242.5-309.8 mbsf); and gravel, clayey siltstone, silty claystone, and sandy silty claystone in three intervals (Subunit IIIB, 309.8-617.8 mbsf).

Four holes were drilled at Site 861: Hole 861A to $9.5 \mathrm{mbsf}$, Hole $861 \mathrm{~B}$ to $9.5 \mathrm{mbsf}$, Hole $861 \mathrm{C}$ to $353.1 \mathrm{mbsf}$, and Hole $861 \mathrm{D}$ to 496.3 mbsf. Drilling at Site 861 penetrated and sampled forearc basin strata on the middle trench slope of the South American continental margin. These are underlain by sediments that may represent the top of an eastward extension of the accretionary wedge intersected at Sites 859 and 860 . The sediments are upper Pleistocene to upper Pliocene.

Three lithologic units were identified at Site 861 (Behrmann, Lewis, Musgrave, et al., 1992). Unit I, 0-43.8 mbsf, consists of silty clays and clayey silts. Subunit IIA, 43.8-208.9 mbsf, is composed of silty clay and clayey silt and contains intercalations of silt, sand, and gravel layers. Subunit IIB, 208.9-351.9 mbsf, is composed of claystone and graded siltstone with intercalations of matrix-supported conglomerates. Unit III, 351.9-496.3 mbsf, is represented by hard silty claystone to clayey siltstone.

Site 862 is located near the crest of Taitao Ridge, a prominent topographic feature along the South American continental margin approximately $25 \mathrm{~km}$ south of the present location of the Chile Triple Junction. Three holes were drilled at Site 862: Hole 862A to $22.1 \mathrm{mbsf}$, Hole $862 \mathrm{~B}$ to $42.9 \mathrm{mbsf}$, and Hole $862 \mathrm{C}$ to $102.1 \mathrm{mbsf}$. Two units were identified. Lithologic Unit I is the thin sediment cover that blankets the Taitao Ridge. Biostratigraphic observations from Site 862 indicate a late Pliocene and Pleistocene age for all of the recovered sediments. The total sediment thickness at the site is about $23 \mathrm{~m}$. Lithologic Unit 


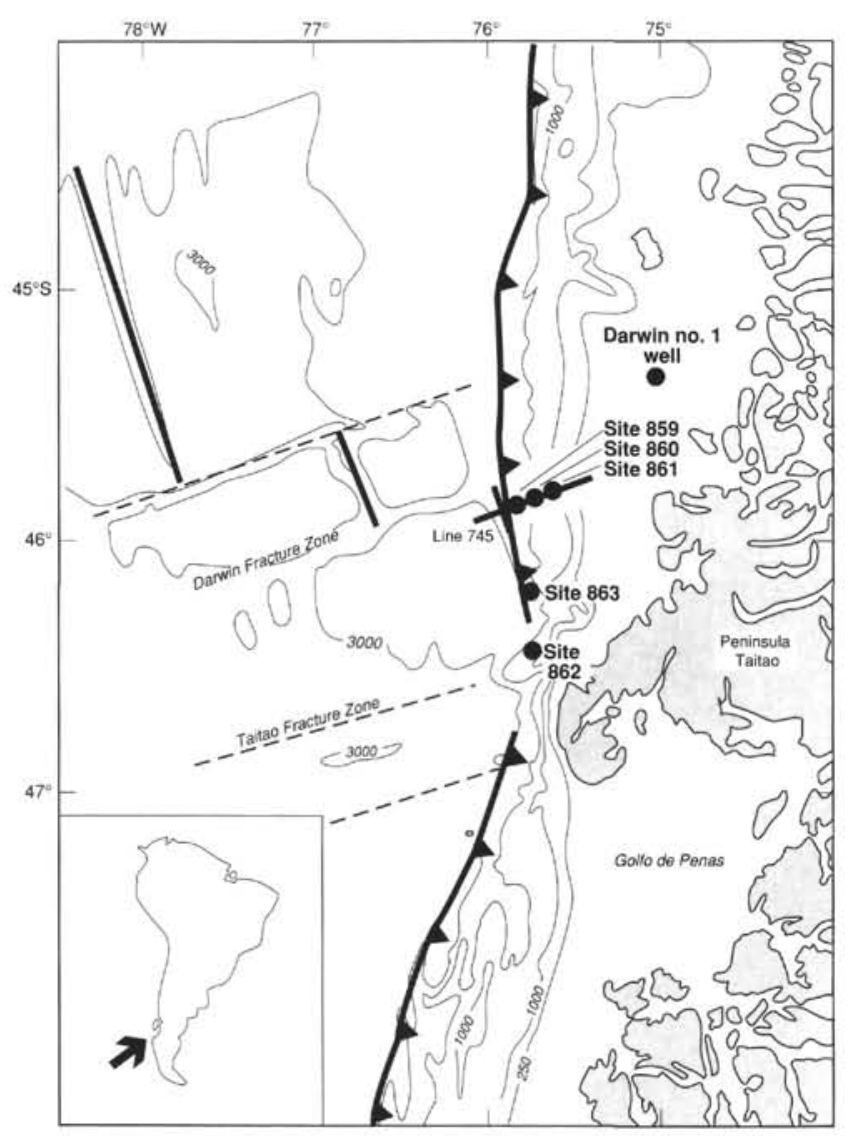

Figure 1. Location map of Leg 141 Sites $859,860,861,862$, and 863.

II is composed of apparently intercalated submarine basalt, dacite, rhyodacite, and rhyolite flows with sporadic sediment interbeds.

According to the shipboard description (Behrmann, Lewis, Musgrave, et al., 1992), the sedimentary blanket on Taitao Ridge recovered at Site 862 is composed of rather uniform fine-grained distal turbidites and low-density suspension fallout deposits, which were subdivided into three subunits differing in their lithification and color. Subunit IB represents simply an indurated lithology of Subunit IA, whereas the transition from Subunits IB to IC is marked by a color change from olive gray (IB) to brownish or yellowish gray (IC), the latter indicating oxidation, possibly resulting from hydrothermal alteration directly above basement.

Site 863 (Hole 863 A to 297.3 mbsf and Hole 863 B to $742.9 \mathrm{mbsf}$ ) is located in the toe region of the accretionary wedge overriding the axial zone of the Chile Ridge about $20 \mathrm{~km}$ north of the ridgetransform intersection with the Taitao Fracture Zone. The sediments, according to the shipboard description (Behrmann, Lewis, Musgrave, et al., 1992), are divided into two lithologic units. Unit I is composed of silt and clay to a depth of 104.4 mbsf (Quaternary to lower Pleistocene $)$ and is divided into two subunits: Subunit IA (0-46.6 mbsf) is composed of silty clay to clayey silt overlying sulfide/organic-rich silty clay to clayey silt with minor sand; Subunit IB (46.6-104.4 mbsf) is composed of silty claystone to clayey siltstone with minor sandstone. Unit II (104.4 to 742.9 mbsf) is composed of lower and upper Pleistocene sandstone and bioturbated siltstone. The bedding in Unit II is predominantly steep to vertical.

\section{METHODS}

Sediments were studied in smear slides. X-ray diffraction (XRD) was applied to bulk powder samples from the clay fraction samples (less than $0.001 \mathrm{~mm}$ ) and to a few samples from the $0.001-0.01-\mathrm{mm}$ fraction. These fractions were separated from suspension using a decantation method and prepared as oriented specimens. In the shorebased laboratory we used a DRON-1.5 X-ray diffractometer with $\mathrm{CuK}$ alpha emission, Ni-filter, and slit openings of $0.5,1,1$, and 0.5 $\mathrm{mm}$. The shipboard Phillips AD $3420 \mathrm{X}$-ray diffractometer was used during the cruise. Each sample was air dried, treated with glycerine or with ethylene glycol, and heated at $550^{\circ} \mathrm{C}$ for $1 \mathrm{hr}$. Clay minerals were semi-quantitatively counted using the method of Biscaye (1965), with the following proposed mean intensity coefficients: smectite:illite (hydromica): chlorite $=1: 4: 2$. The sum of three clay minerals is taken equal to $100 \%$.

Clay minerals in the sediments were identified using the following criteria.

Smectites are characterized by a strong first-order basal reflection $14 \AA$, which shifts to $17 \AA$ after saturation with ethylene glycol and by weak reflections appearing at about $8.5 \AA(002), 5.6 \AA(003)$, and $3.33 \AA(005)$. After heating to $550^{\circ} \mathrm{C}$, the reflection $(001)$ is at $10 \AA$.

Hydromica is readily recognized by a series of reflections based on its $10 \AA$ periodicity. The intensity ratio of the first three basal reflections (at 10,5 , and $3.33 \AA$ ) identifies the hydromica as a dioctahedral $\mathrm{Fe}-\mathrm{Al}$ variety. It may be a polytype modification of hydromica $2 \mathrm{M}_{1}$ (of muscovitic type).

Chlorite is identified by a series of basal reflections based on a 14.1 $\AA$ periodicity. Ratios of reflection peaks at $7.1 \AA(002)$ and $3.5 \AA$ (004) to those at $14.1 \AA(001)$ and $4.7 \AA(003)$ identify the chlorite in sediments as the $\mathrm{Fe}-\mathrm{Mg}$ trioctahedral variety.

The coarse fraction $(0.1-0.05 \mathrm{~mm})$ was separated by wet sieving and studied using the immersion method. The heavy and light fractions were separated in bromoform $\left(2.9 \mathrm{~g} / \mathrm{cm}^{3}\right), 300$ to 400 grains were counted in both fractions. To produce more expressive triangular and linear diagrams, we subtracted the opaque minerals from the heavy minerals and the rock fragments from the light minerals and then counted the sum of the remaining transparent minerals as $100 \%$ for the heavy and light fractions, respectively.

SEM was used to observe newly formed hydrothermal minerals in the sediments from Sites 863 and 862 .

Some samples from within a holes were analyzed by both routine wet chemistry and spectral methods.

\section{MINERALOGY OF SEDIMENTS}

Our mineralogical study focused mainly on differences in the Pleistocene to Pliocene terrigenous sediment sequences within the accretionary wedge (transect across the trench slope prior to ridge collision, Sites 859,860 , and 861) and on hydrothermal effects caused by fluid circulation from the subducted spreading ridge.

\section{Mineralogy of Sediments from the Continental Trench Slope (Sites 859, 860, and 861)}

\section{Site 859}

The shipboard XRD study (op. cit.) of 37 bulk powder samples from Unit II (10 to $467 \mathrm{mbsf}$ ) in Holes 859A and 859B showed that quartz is the dominant mineral. Feldspars are the secondmost abundant phase. The same sediments were identified by smear-slide description. Most of the samples contain minor or trace amounts of hornblende, with an amorphous phase present in all samples. Overall, the samples studied are highly similar in the types and relative abundances of minerals (Behrmann, Lewis, Musgrave, et al., 1992).

The coarse-fraction mineralogy results are shown in Tables 1 and 2 (heavy and light fractions, respectively). Both the heavy and light fractions demonstrate a fairly uniform mineral composition for the terrigenous sediments.

The hornblende and epidote group predominate in the heavy fraction and together form more than $70 \%$ of transparent minerals. The 
Table 1. Coarse fraction (0.01-0.05 mm) mineralogy of Leg 141 heavy minerals.

\begin{tabular}{|c|c|c|c|c|c|c|c|c|c|c|c|c|c|c|}
\hline $\begin{array}{l}\text { Core, section, } \\
\text { interval }(\mathrm{cm})\end{array}$ & $\begin{array}{l}\text { Depth } \\
\text { (mbsf) }\end{array}$ & $\begin{array}{l}\text { Opaque } \\
\text { minerals }\end{array}$ & $\mathrm{Gr}$ & $\mathrm{Hb}$ & $\mathrm{Ac}$ & Opx & $\mathrm{Cpx}$ & Ep & 01 & $\mathrm{Zr}$ & Ap & $\mathrm{Tu}$ & Sph & Sum \\
\hline \multicolumn{15}{|l|}{$141-859 \mathrm{~A}-$} \\
\hline $\begin{array}{l}3 \mathrm{H}-3.89-92 \\
5 \mathrm{H}-4.49-54\end{array}$ & $\begin{array}{l}14.59 \\
28.03\end{array}$ & $\begin{array}{l}53 \\
55\end{array}$ & $\begin{array}{l}1 \\
1\end{array}$ & $\begin{array}{l}26 \\
29\end{array}$ & $\begin{array}{l}1 \\
1\end{array}$ & $\frac{2}{2}$ & $\begin{array}{l}5 \\
3\end{array}$ & $\begin{array}{l}9 \\
7\end{array}$ & $\begin{array}{l}0 \\
0\end{array}$ & 1 & 1 & $\begin{array}{l}0 \\
0\end{array}$ & $\begin{array}{l}1 \\
0\end{array}$ & $\begin{array}{l}100 \\
100\end{array}$ \\
\hline \multicolumn{15}{|l|}{ 141-859B- } \\
\hline $2 \mathrm{R}-3,89-92$ & 65.49 & 25 & 1 & 39 & 4 & 2 & 4 & 21 & 0 & 1 & 2 & 1 & 0 & 100 \\
\hline $4 \mathrm{R}-1.123-125$ & 141.23 & 44 & 1 & 26 & 1 & 2 & 9 & 14 & 0 & 1 & 1 & 0 & 1 & 100 \\
\hline IIR-1. 65-68 & 207.50 & 28 & $i$ & 34 & i & 5 & 8 & 19 & 0 & i & 2 & 0 & $i$ & 100 \\
\hline $12 \mathrm{R}-3,50-52$ & 218.80 & 35 & 0 & 26 & 2 & 2 & 8 & 23 & 0 & 2 & 2 & 0 & 0 & 100 \\
\hline $20 \mathrm{R}-3,115-118$ & 297.35 & 1.3 & 1 & 48 & 2 & 5 & 5 & 20 & 0 & 1 & 2 & 0 & 3 & 100 \\
\hline $32 R-2,31-33$ & 409.91 & 52 & I & 20 & 1 & 1 & 3 & 18 & 0 & 1 & $\vec{I}$ & 1 & 1 & 100 \\
\hline $38 R-1.78-81$ & 467.18 & 41 & 1 & 24 & 1 & 1 & 3 & 24 & 0 & 1 & 2 & 0 & 2 & 100 \\
\hline \multicolumn{14}{|l|}{ 141-860A- } & 100 \\
\hline \multicolumn{15}{|l|}{$141-860 \mathrm{~B}-$} \\
\hline $5 \mathrm{H}-2,51-54$ & 31.91 & 32 & 1 & 36 & 4 & 1 & 11 & 10 & 3 & 1 & 1 & 0 & 0 & 100 \\
\hline $16 X-2,42-45$ & 118.72 & 28 & 0 & 31 & 6 & 3 & 10 & 18 & 0 & 0 & 3 & 0 & 1 & 100 \\
\hline $17 X-5.103-106$ & 133.53 & 36 & 1 & 26 & 4 & 2 & 9 & 19 & 1 & 0 & 1 & 0 & 1 & 100 \\
\hline $24 X-1,81-83$ & 185,21 & 67 & 0 & 10 & 3 & 1 & 6 & 8 & 4 & 0 & $i$ & 0 & 0 & 100 \\
\hline $25 X-1.70-73$ & 194.80 & 24 & 1 & 31 & 2 & $i$ & 14 & 25 & 0 & 1 & $i$ & 0 & 0 & 100 \\
\hline $32 X-2,24-27$ & 262.60 & 21 & 0 & 40 & 2 & 4 & 11 & 19 & 0 & i & i & 0 & 1 & 100 \\
\hline $36 \times-3,14-19$ & 303.24 & 35 & I & 32 & 4 & 3 & 9 & 13 & 0 & i & i & 0 & i & 100 \\
\hline $41 X-3.65-68$ & 351.65 & 55 & 0 & 11 & 2 & 4 & 10 & 16 & 0 & 1 & 1 & 0 & 0 & 100 \\
\hline $51 X-1.103-106$ & 435.83 & 39 & 0 & 32 & 1 & $i$ & 7 & 16 & 0 & $i$ & 2 & I & 0 & 100 \\
\hline $61 \times-4,103-106$ & 527.23 & 47 & 1 & 30 & 3 & 2 & 6 & 9 & 0 & 1 & 1 & 0 & 0 & 100 \\
\hline $66 X-1.55-57$ & 570.05 & 52 & $i$ & 14 & i & i & 9 & 20 & 0 & $i$ & $i$ & 0 & 0 & 100 \\
\hline \multicolumn{15}{|l|}{$141-861 \mathrm{C}$} \\
\hline $2 \mathrm{H}-3.77-82$ & 6.77 & 81 & 0 & 1 & 1 & 1 & 3 & 9 & 0 & 1 & 1 & 0 & 2 & 100 \\
\hline $4 \mathrm{H}-3,94-99$ & 25.94 & 36 & 0 & 24 & 2 & 4 & 13 & 17 & 1 & 1 & 0 & 0 & 2 & 100 \\
\hline $7 \mathrm{H}-6,41-44$ & 58.41 & 38 & 0 & 30 & 2 & i & 14 & II & $i$ & 0 & 1 & 1 & 1 & 100 \\
\hline $8 \mathrm{H}-3,13-16$ & 63.13 & 52 & 1 & 23 & 2 & 2 & 6 & 9 & 1 & 1 & 1 & 1 & 1 & 100 \\
\hline $14 X-2,103-108$ & 111.93 & 20 & 0 & 37 & 2 & 4 & 16 & 15 & $i$ & 1 & 1 & i & 2 & 100 \\
\hline $22 X-5.95-98$ & 186.85 & 22 & 1 & 36 & 3 & 3 & 12 & 17 & 0 & 1 & 2 & 0 & 3 & 100 \\
\hline $28 X-2.78-83$ & 230.38 & 37 & i & 28 & 3 & 4 & 11 & 12 & 1 & 1 & 1 & I & 0 & 100 \\
\hline $37 X-2,103-106$ & 307.43 & 41 & 1 & 25 & 2 & 2 & 9 & 17 & 0 & 1 & 1 & 0 & 1 & 100 \\
\hline \multicolumn{15}{|l|}{ 141-86ID- } \\
\hline $7 R-2,16-19$ & 401.76 & 49 & 0 & 26 & 1 & 2 & 5 & 14 & 0 & 1 & I & 0 & 1 & 100 \\
\hline $11 R-2,11-16$ & 440.11 & 64 & 1 & 16 & 1 & 3 & 6 & 6 & 0 & I & I & 0 & I & 100 \\
\hline $16 \mathrm{R}-1.112-117$ & 487.12 & 40 & i & 31 & 1 & 1 & 4 & 19 & 0 & $i$ & 1 & 0 & 1 & 100 \\
\hline \multicolumn{15}{|l|}{$141-862 \mathrm{~A}-$} \\
\hline $1 \mathrm{H}-1,21-24$ & 0.21 & 53 & I & 3 & 3 & 5 & 19 & 10 & 1 & 1 & 2 & 0 & 2 & 100 \\
\hline $2 \mathrm{H}-\mathrm{I}, 49-52$ & 5.89 & 39 & 0 & 22 & 2 & 6 & 14 & 12 & 2 & $i$ & 1 & 0 & 1 & 100 \\
\hline $3 \mathrm{H}-4.78-81$ & 20.18 & 16 & 0 & 42 & 3 & 4 & 12 & 18 & 0 & $i$ & 2 & 1 & i & 100 \\
\hline $4 \mathrm{H}-1,10-13$ & 20.70 & 38 & 1 & 21 & 0 & 4 & 8 & 10 & 16 & 1 & 0 & 0 & 1 & 100 \\
\hline $4 \mathrm{H}-\mathrm{CC}, 8-11$ & 20.96 & 66 & 0 & 8 & 0 & 3 & 1 & 1 & 21 & 0 & 0 & 0 & 0 & 100 \\
\hline \multicolumn{15}{|l|}{$141-863 \mathrm{~A}-$} \\
\hline $2 \mathrm{H}-2,82-87$ & 10.92 & 42 & 1 & 27 & 2 & 1 & 11 & 12 & 0 & 1 & 1 & 1 & 1 & 100 \\
\hline $7 X-3,87-90$ & 59.97 & 26 & 1 & 42 & 4 & 4 & 6 & 14 & 0 & 1 & 1 & 0 & 1 & 100 \\
\hline $19 \times-1,29-32$ & 172.29 & 13 & 1 & 49 & 4 & 4 & 10 & 14 & 0 & i & 3 & 0 & 1 & 100 \\
\hline $31 X-C C .15-17$ & 280.98 & 15 & 1 & 47 & 2 & 3 & 8 & 20 & 0 & 1 & 1 & 1 & 1 & 100 \\
\hline \multicolumn{15}{|l|}{$141-863 \mathrm{~B}-$} \\
\hline $\mid 0 R-1.48-51$ & 371.48 & 21 & 0 & 43 & 2 & 4 & 13 & 1.3 & 1 & 1 & 1 & 0 & 1 & 100 \\
\hline $18 \mathrm{R}-1.39-42$ & 444.39 & 33 & 2 & 36 & 3 & 0 & 7 & 15 & 1 & 1 & 2 & 0 & 0 & 100 \\
\hline $23 \mathrm{R}-1,105-109$ & 493.45 & 33 & i & 28 & 2 & 3 & 6 & 22 & 0 & i & 2 & 0 & 2 & 100 \\
\hline $38 R-3,16-19$ & 639.76 & 9 & I & 56 & 1 & 1 & 6 & 20 & 1 & 1 & 2 & 1 & 1 & 100 \\
\hline $44 R-4,104-108$ & 699.99 & 3 & i & 66 & 4 & 2 & 4 & 16 & 0 & 1 & 2 & 0 & I & 100 \\
\hline $49 R-4.97-100$ & 738.67 & 13 & i & 67 & $i$ & 1 & $i$ & 11 & 0 & 2 & 1 & 1 & i & 100 \\
\hline
\end{tabular}

hornblende content is higher than that of epidote; however, the difference decreases downhole to zero in the lowermost sample ( $467 \mathrm{mbsf}$ ). Pyroxenes are the next group in abundance, and clinopyroxene commonly predominates over orthopyroxene. Actinolite-tremolite and chlorite are present in minor amounts. Accessory minerals are garnet, zircon, apatite, tourmaline, and sphene, which together are less than $10 \%$ of the transparent heavy minerals. Opaque minerals include magnetite, pyrite (diagenetic), iron oxides, and rock fragments.

Quartz is highly predominant (about $60 \%$ ) among the non-rock fragment light minerals. Feldspars, which are commonly dominated by plagioclase, comprise $20 \%$ to $38 \%$, except for a Sample 141859B-4R-1, 123-125 cm (141 mbsf) with abundant (30\%) volcanic glass. In other samples the vitric constituent is low or absent.

Thus, we cannot recognize any distinct changes in the coarsefraction mineralogy with age or by lithologic unit.
The clay fraction is dominated by hydromica and chlorite, which together comprise $66 \%$ to $94 \%$ of the sum of clay minerals, with lesser amounts of smectite (Table 3).

The downhole distribution of clay minerals in the samples from Holes $859 \mathrm{~A}$ and $859 \mathrm{~B}$ shows a ubiquitous and relatively constant chlorite content throughout the sedimentary sequence. Smectite and hydromica are, in general, also relatively constant.

Diagenetic processes have apparently not affected hydromica or chlorite with stable crystalline structure. The distribution of these minerals in Holes 859A and 859B is thought to reflect variations in either sedimentary processes or the primary composition of the terrigenous clay minerals derived from the source area.

The mineralogical data obtained from the deformed sediments of the accretionary wedge and from the hemipelagic slope blanket on the leading edge of the South American forearc basement confirm the 
Table 2. Coarse fraction (0.01-0.05 mm) mineralogy of Leg 141 light minerals.

\begin{tabular}{|c|c|c|c|c|c|c|c|c|c|}
\hline $\begin{array}{l}\text { Core, section. } \\
\text { interval }(\mathrm{cm})\end{array}$ & $\begin{array}{l}\text { Depth } \\
\text { (mbsf) }\end{array}$ & $\mathrm{Qz}$ & $\mathrm{Kf}$ & $\mathrm{Pi}$ & $\mathrm{Mc}$ & $\mathrm{Vg}$ & RF & Carb & Sum \\
\hline \multicolumn{10}{|l|}{$141-859 \mathrm{~A}-$} \\
\hline $3 \mathrm{H}-3,89-92$ & 14.59 & 40 & 5 & 12 & 0 & 6 & 37 & 0 & 100 \\
\hline $5 \mathrm{H}-4.49-54$ & 28.03 & 50 & 8 & 11 & 1 & 15 & 14 & 1 & 100 \\
\hline \multicolumn{10}{|l|}{$141-859 \mathrm{~B}-$} \\
\hline $2 \mathrm{R}-3,89-92$ & 65.49 & 39 & 6 & 12 & 1 & 7 & 35 & 0 & 100 \\
\hline $4 R-1,123-125$ & 141.23 & 46 & 1 & 6 & 0 & 24 & 22 & 1 & 100 \\
\hline IIR-1. $65-68$ & 207.50 & 27 & 4 & 8 & 1 & 5 & 55 & 0 & 100 \\
\hline $12 \mathrm{R}-3.50-52$ & 218.80 & 14 & 1 & 3 & 1 & 3 & 78 & 0 & 100 \\
\hline $2 \mathrm{OR}-3.115-118$ & 297.35 & 42 & 7 & 16 & i & 1 & 33 & 0 & 100 \\
\hline $32 R-2.31-33$ & 409.91 & 40 & 20 & 12 & 1 & 0 & 27 & 0 & 100 \\
\hline $38 R-1.78-81$ & 467.18 & 40 & 9 & 7 & 0 & 7 & 33 & 4 & 100 \\
\hline \multicolumn{10}{|l|}{$141-860 \mathrm{~A}-$} \\
\hline \multicolumn{10}{|l|}{$141-860 \mathrm{~B}-$} \\
\hline $5 \mathrm{H}-2.5 \mathrm{I}-54$ & 31.91 & 33 & 8 & 14 & 0 & 10 & 34 & 1 & 100 \\
\hline $16 \times-2.42-45$ & 118.72 & 33 & 8 & 17 & 1 & 7 & 34 & 0 & 100 \\
\hline $17 X-5.103-106$ & 133.53 & 33 & 9 & 14 & i & 2 & 41 & 0 & 100 \\
\hline $24 X-1.81-83$ & 185.21 & 35 & 4 & 15 & 0 & 9 & 36 & 1 & 100 \\
\hline $25 x-1.70-73$ & 194.80 & 31 & 6 & 14 & 1 & 9 & 38 & $i$ & 100 \\
\hline $32 X-2,24-27$ & 262.60 & 23 & 5 & 20 & 0 & 5 & 46 & 1 & 100 \\
\hline $36 \times-3,14-19$ & 303.24 & 24 & 4 & 12 & 1 & 8 & 51 & 0 & 100 \\
\hline $41 \times-3.65-68$ & 351.65 & 27 & 6 & 8 & 0 & 5 & 53 & 1 & 100 \\
\hline $51 X-1.103-106$ & 435.83 & 20 & 3 & 8 & 1 & 3 & 65 & 0 & 100 \\
\hline $61 \times-4 \cdot 103-106$ & 527.23 & 26 & 5 & 18 & i & 6 & 43 & 1 & 100 \\
\hline $66 \times-1.55-57$ & 570.05 & 15 & 5 & 8 & 1 & 3 & 67 & 1 & 100 \\
\hline \multicolumn{10}{|l|}{$141-861 \mathrm{C}$} \\
\hline $2 \mathrm{H}-3,77-82$ & 6.77 & 39) & 8 & 9 & 2 & 9 & 26 & 7 & 100 \\
\hline $4 \mathrm{H}-3,94-99$ & 25.94 & 30 & 7 & 15 & 2 & 5 & 39 & 2 & 100 \\
\hline $7 \mathrm{H}-6.41-44$ & 58.41 & 31 & 5 & 14 & 0 & 20 & 28 & 2 & 100 \\
\hline $8 \mathrm{H}-3,13-16$ & 63.13 & 52 & 5 & 9 & 2 & 0 & 31 & I & 100 \\
\hline $14 X-2,103-108$ & 111.93 & 37 & 4 & 16 & 2 & 8 & 31 & 2 & 100 \\
\hline $22 \times-5.95-98$ & 186.85 & 32 & 4 & 17 & 0 & 12 & 34 & 1 & 100 \\
\hline $28 X-2,78-83$ & 230.38 & 36 & 0 & 17 & 2 & 9 & 35 & 1 & 100 \\
\hline $37 X-2,103-106$ & 307.43 & 35 & 6 & 18 & 2 & 11 & 26 & 2 & 100 \\
\hline \multicolumn{10}{|l|}{ |41-86|D- } \\
\hline 7R-2. 16-19 & 401.76 & 16 & 6 & 17 & 1 & 9 & 47 & 4 & 100 \\
\hline IIR-2. II-16 & 440.11 & 4 & 1 & 2 & I & 0 & 90 & 2 & 100 \\
\hline $16 \mathrm{R}-1.112-117$ & 487.12 & 25 & 6 & 12 & 2 & 2 & 52 & I & 100 \\
\hline \multicolumn{10}{|l|}{$141-862 \mathrm{~A}-$} \\
\hline IH-1.21-24 & 0.21 & 12 & 5 & 15 & 1 & 23 & 28 & 16 & 100 \\
\hline $2 \mathrm{H}-1.49-52$ & 5.89 & 21 & 7 & 18 & 1 & 9 & 44 & 0 & 100 \\
\hline $3 \mathrm{H}-4.78-81$ & 20.18 & 24 & 10 & 10 & $i$ & 30 & 25 & 0 & 100 \\
\hline $4 \mathrm{H}-1.10-13$ & 20.70 & 4 & 0 & 12 & 0 & 56 & 28 & 0 & 100 \\
\hline $4 \mathrm{H}-\mathrm{CC} .8-11$ & 20.96 & 5 & 0 & 17 & 1 & 54 & 23 & 0 & 100 \\
\hline \multicolumn{10}{|l|}{$141-86.3 \mathrm{~A}-$} \\
\hline $2 \mathrm{H}-2.82-87$ & 10.92 & 33 & 9 & 14 & I & 6 & 36 & 1 & 100 \\
\hline $7 X-3.87-90$ & 59.97 & 28 & 7 & 16 & 0 & 9 & 40 & 0 & 100 \\
\hline $19 \times-1.29-32$ & 172.29 & 34 & 9 & 16 & 0 & 5 & 36 & 0 & 100 \\
\hline $31 X-C C .15-17$ & 280.98 & 31 & 6 & 10 & 0 & 5 & 48 & 0 & 100 \\
\hline \multicolumn{10}{|l|}{$141-863 \mathrm{~B}-$} \\
\hline |OR-1. $48-51$ & 371.48 & 20 & 0 & 12 & 1 & 22 & 45 & 0 & 100 \\
\hline $18 \mathrm{R}-1.39-42$ & 444.39 & 14 & 3 & 2 & 4 & 1 & 73 & 4 & 100 \\
\hline $23 R-1.105-109$ & 493.45 & 26 & 5 & 12 & 2 & 3 & 51 & 1 & 100 \\
\hline $38 R-3.16-19$ & 639.76 & 36 & 4 & 15 & 2 & 2 & 41 & 0 & 100 \\
\hline $44 R-4.104-108$ & 699.99 & 45 & 5 & 11 & 2 & 0 & 36 & 1 & 100 \\
\hline $49 \mathrm{R}-4.97-100$ & 738.67 & 41 & 3 & 18 & 2 & 0 & 35 & 1 & 100 \\
\hline
\end{tabular}

conclusion of the shipboard sedimentologists, that the sediments cored at Site 859 are uniform in their mineralogical composition throughout the section recovered.

\section{Site 860}

The shipboard XRD study of 51 bulk powder samples shows that the dominant minerals in all of the samples from Hole $860 \mathrm{~B}$ are quartz and feldspar with only small fluctuations in their abundance. All of the samples contain minor to trace amounts of hornblende. An amorphous phase is present in all samples. Overall, the mineral composition is uniform throughout the section recovered (Behrmann, Lewis, Musgrave, et al., 1992).

Heavy minerals in the coarse fraction (Table 1) are dominated by hornblende and epidote and the light fraction (Table 2) is dominated by quartz and feldspar in proportions similar to those at Site 859. However, there are some differences from the latter: pyroxenes (mainly clinopyroxene) are higher relative to hornblende; olivine occurs sporadically and "sialic" accessories, especially tourmaline, are very rare in the heavy fraction, and feldspars (especially plagioclase) are higher relative to quartz in the light fraction. The downhole distribution of transparent minerals in both the heavy and light fractions is rather uniform. Scattered changes in the relative proportions of hornblende, epidote, and pyroxenes in the heavy fraction and plagioclase and quartz in the light fraction have no distinct relation to either sediment age or lithologic unit.

The major part of the clay fraction (less than $0.001 \mathrm{~mm}$ ) consists of hydromica and chlorite, which together comprise $78 \%$ to $97 \%$ of the sum of the clay minerals (Table 3 ). The remainder (3\% to $22 \%$ ) is composed of smectites. The distribution of clay minerals in samples from Hole $860 \mathrm{~B}$ shows ubiquitous and relatively constant downhole contents of hydromica, chlorite, and smectite. In general, the content of smectite in the clay fraction is low. The maximum concentration of smectite (22\%) is found in Sample 141-860B-41X-3, 70-72 cm ( $351.70 \mathrm{mbsf}$ ). The sediments from Hole $860 \mathrm{~B}$ contain less smectite than those from Hole 859A.

\section{Site 861}

The shipboard XRD data show that bulk sediment samples from both Holes $861 \mathrm{C}$ and $861 \mathrm{D}$ are similar overall in the presence and relative abundance of mineral phases. The dominant minerals are quartz and feldspars with only small variations in their abundance. All of the samples contain an amorphous phase and minor to trace amounts of hornblende (Behrmann, Lewis, Musgrave, et al., 1992).

The heavy minerals (Table 1) show a rather uniform distribution in the sedimentary sequence recovered at Site 861 . Hornblende strongly predominates in lithologic Units II and III ( $40 \%-50 \%$ of the transparent minerals), whereas the epidote and clinopyroxene concentrations are almost equal in most of the samples from below 25 mbsf ( $19 \%$ to $31 \%$ and $10 \%$ to $21 \%$, respectively). Unit I, especially in the uppermost Sample 141-861C-2H-3, 77-82 cm (6.77 mbsf), differs in that it contains less hornblende and more epidote and sialic accessories. However, the opaque minerals are very abundant (81\%) in the uppermost sample; therefore, counting the transparent minerals is not highly reliable.

The general proportions of minerals in the light fraction are almost the same as at the downslope Sites 859 and 860 . Their oscillations are rather irregular and do not correspond with the lithologic units and ages. The most significant variations in volcanic glass content $(0$ to almost $30 \%$ ) seem inversely proportional to quartz and the quartz/ feldspar ratio, which possibly indicates the proportion of volcaniclastic constituents relative to terrigenous matter.

The clay minerals in the fraction smaller than $0.001 \mathrm{~mm}$ (Table 3) show a rather uniform distribution throughout the sediment sequence at Site 861; as at Sites 859 and 860 , the clay fraction is dominated by hydromica and chlorite with minor smectite. A smectite maximum (23\%) was found in Sample 141-861C-40X-2, 30-33 cm (335.7 mbsf).

\section{Mineralogy of Sediments from the Lower Trench Slope after the Ridge Collision (Site 863)}

The shipboard XRD analysis of the 25 bulk powdered samples from Site 863 (Behrmann, Lewis, Musgrave, et al., 1992) showed that in the sediments from 4.6 to $738.6 \mathrm{mbsf}$, the dominant minerals are quartz and feldspars with only small fluctuations in their abundances. All of the samples contain minor to trace amounts of hornblende. Calcite is rare overall, and is present only in trace to minor amounts in cores below 141-863A-20X (182 mbsf). However, carbonate is locally concentrated in burrow fillings and veins, as well as in patches of calcite-cemented sand. Disseminated pyrite occurs in trace amounts. 
Table 3. Results of X-ray diffraction clay mineralogy in the fraction less than $0.001 \mathrm{~mm}$ with the $0.001-0.01-\mathrm{mm}$ fraction in parentheses.

\begin{tabular}{|c|c|c|c|c|c|c|c|c|c|}
\hline $\begin{array}{l}\text { Core, section. } \\
\text { interval }(\mathrm{cm})\end{array}$ & $\begin{array}{l}\text { Depth } \\
\text { (mbsf) }\end{array}$ & $\begin{array}{l}\text { Smectite } \\
(\%)\end{array}$ & $\begin{array}{l}\text { Hydromica } \\
(\%)\end{array}$ & $\begin{array}{l}\text { Chlorite } \\
\text { (\%) }\end{array}$ & $\begin{array}{l}\text { Core, section. } \\
\text { interval }(\mathrm{cm})\end{array}$ & $\begin{array}{l}\text { Depth } \\
\text { (mbst) }\end{array}$ & $\begin{array}{c}\text { Smectite } \\
(\%)\end{array}$ & $\begin{array}{l}\text { Hydromica } \\
(\%)\end{array}$ & $\begin{array}{c}\text { Chlorite } \\
\text { (\%) }\end{array}$ \\
\hline $141-859 \mathrm{~A}=$ & & & & & $40 \times-2,30-33$ & 335.70 & 23 & 40 & 37 \\
\hline IH-I. 69-72 & 0.69 & 13 & 52 & 35 & $41 \times-2,76-79$ & 345.66 & 11 & 53 & 36 \\
\hline $2 \mathrm{H}-4,10-12$ & 5.80 & 2 & 60 & 38 & & & & & \\
\hline $4 \mathrm{H}-4.78-80$ & 21.98 & 7 & 49 & 44 & 141-861D- & & & & \\
\hline $6 X-1.67-73$ & 35.37 & 12 & 51 & 37 & $6 R-2,10-13$ & 391.37 & 10 & 48 & 42 \\
\hline $11 X-3.72-75$ & 72.02 & 5 & 58 & 37 & $10 R-1.72-77$ & 429.82 & 9 & 45 & 46 \\
\hline $14 X-2.39-43$ & 89.41 & 5 & 62 & 33 & $12 R-2,48-53$ & 450.48 & 4 & 61 & 35 \\
\hline \multicolumn{5}{|l|}{$141-8.59 \mathrm{~B}-$} & $15 R-1.42-47$ & 476.72 & 8 & 49 & 43 \\
\hline 10R-3. 27-34 & 199.97 & 5 & 60 & 35 & $141-862 \mathrm{~A}-$ & & & & \\
\hline IIR-1. $72-74$ & 207.12 & 23 & 45 & 32 & $\mid \mathrm{H}-1,2 \mathrm{I}-24$ & 0.21 & $14(6)$ & $46(56)$ & $40(38)$ \\
\hline $12 \mathrm{R}-3.64-66$ & 218.94 & 23 & 52 & 25 & $1 \mathrm{H}-1,114-116$ & 0.93 & $4(2)$ & $64(64)$ & $32(34)$ \\
\hline $13 \mathrm{R}-7,121-123$ & 2.33 .74 & 23 & 42 & 35 & IH-2. 19-22 & 1.69 & $6(3)$ & $62(62)$ & $32(35)$ \\
\hline $15 \mathrm{R}-2.78-81$ & 247.28 & 22 & 36 & 42 & $1 \mathrm{H}-3,110-113$ & 4.10 & $5(3)$ & $62(58)$ & $33(39)$ \\
\hline $16 \mathrm{R}-4,103-105$ & 260.13 & 34 & 32 & 34 & $2 \mathrm{H}-1,49-52$ & 5.89 & $7(2)$ & $54(60)$ & $39(38)$ \\
\hline $20 \mathrm{R}-3,47-49$ & 296.67 & 18 & 39 & 43 & $2 \mathrm{H}-3.119-122$ & 9.59 & $12(4)$ & $50(53)$ & $38(43)$ \\
\hline $23 R-2.46-48$ & 323.80 & 26 & 36 & 38 & $2 \mathrm{H}-3.136-138$ & 9.76 & $9(6)$ & $42(53)$ & $49(41)$ \\
\hline $25 \mathrm{R}-3.100-102$ & 345.20 & 18 & 52 & 30 & $2 \mathrm{H}-5.55-58$ & 11.95 & $7(6)$ & $53(52)$ & $40(42)$ \\
\hline $28 R-4.75-77$ & 375.35 & 32 & 46 & 22 & $2 \mathrm{H}-7.40-43$ & 14.80 & $7(4)$ & $54(57)$ & $39(39)$ \\
\hline $30 R-3.63-65$ & 392.83 & 15 & 50 & 35 & $3 \mathrm{H}-3,103-106$ & 18.93 & $8(7)$ & $44(50)$ & $48(43)$ \\
\hline $33 R-1,69-71$ & 418.99 & 6 & 58 & 36 & $3 \mathrm{H}-4,34-36$ & 19.74 & 9 & 44 & \\
\hline $36 \mathrm{R}-1.103-108$ & 448.13 & 9 & 57 & 34 & $3 H-4,61-64$ & 20.01 & $7(2)$ & $46(60)$ & $47(38)$ \\
\hline \multirow[t]{2}{*}{$38 R-1,94-96$} & 467.34 & 10 & 57 & 33 & $3 \mathrm{H}-4,65-68$ & 20.05 & $12(4)$ & $42(52)$ & $46(44)$ \\
\hline & & & 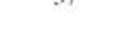 & 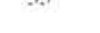 & $3 \mathrm{H}-4,78-81$ & 20.18 & $5(4)$ & $51(53)$ & $44(43)$ \\
\hline 141-860B- & & & & & $3 \mathrm{H}-4,103-105$ & 20.43 & 11 & 49 & \\
\hline $1 \mathrm{H}-1.34-36$ & 0.34 & 4 & 58 & 38 & $3 \mathrm{H}-4,115-118$ & 20.55 & $20(10)$ & $42(50)$ & $38(40)$ \\
\hline $3 \mathrm{H}-4.84-86$ & 6.24 & 4 & 49 & 47 & $4 \mathrm{H}-\mathrm{I}, 10-13$ & 20.70 & $8(4)$ & $53(59)$ & $39(37)$ \\
\hline $5 \mathrm{H}-2,54-56$ & 31.94 & 5 & 52 & 43 & $4 \mathrm{H}-\mathrm{CC} .8-11$ & 20.96 & $7(5)$ & $51(51)$ & $42(44)$ \\
\hline $7 \mathrm{H}-4,27-29$ & 53.67 & 11 & 44 & 45 & & & & & \\
\hline $12 X-2,89-90$ & 90.09 & 6 & 52 & 42 & 141-862B- & & & & \\
\hline $16 X-2,54-55$ & 118.84 & 14 & 46 & 40 & $2 X-1.110-112$ & 18.60 & $15(6)$ & $37(51)$ & $48(43)$ \\
\hline $17 X-5.100-102$ & 133.50 & 4 & 60 & 36 & $2 X-1.113-115$ & 18.63 & $14(7)$ & $44(50)$ & $42(43)$ \\
\hline $19 X-3.94-96$ & 141.04 & 9 & 44 & 47 & $2 \mathrm{X}-\mathrm{CC} .21-25$ & 21.48 & $6(3)$ & $42(47)$ & $52(50)$ \\
\hline $22 X-2,106-108$ & 167.66 & 6 & 42 & 52 & $2 \mathrm{X}-\mathrm{CC} .30-33$ & 21.57 & $5(6)$ & $51(50)$ & $44(44)$ \\
\hline $24 X-1.87-90$ & 185.27 & 3 & 62 & 35 & & & & & \\
\hline $25 X-1,67-69$ & 194.77 & 4 & 53 & 43 & $\begin{array}{l}141-862 C- \\
1 W-18-21\end{array}$ & 39.78 & $7(3)$ & $56(62)$ & $37(35)$ \\
\hline $28 X-1,110-112$ & 224.20 & 10 & 44 & 46 & & 39.78 & $(3)$ & $90(02)$ & $3 /(53)$ \\
\hline $32 \times-2,28-32$ & 262.64 & 11 & 48 & 41 & $141-863 \mathrm{~A}-$ & & & & \\
\hline $33 X-1.49-52$ & 271.69 & 12 & 43 & 45 & IH-3. $130-132$ & 4.30 & 5 & 58 & \\
\hline $36 X-3,58-60$ & 303,68 & 5 & 54 & 41 & $\mathrm{IH}-4.56-59$ & 5.06 & $4(2)$ & $53(49)$ & $43(49)$ \\
\hline $38 X-1,117-119$ & 320.57 & 8 & 48 & 44 & $2 \mathrm{H}-2,82-87$ & 10.92 & $4(1)$ & $57(54)$ & $39(45)$ \\
\hline $41 X-3,70-72$ & 351.70 & 22 & 44 & 34 & $5 \mathrm{H}-2,116-118$ & 39.76 & 4 & 56 & \\
\hline $44 X-C C .10-11$ & 367.40 & 6 & 49 & 45 & $7 X-3,87-90$ & 59.97 & $7(8)$ & $47(46)$ & $46(46)$ \\
\hline $45 \mathrm{X}-\mathrm{CC} .37-39$ & 377.27 & 5 & 54 & 41 & $10 X-C C, 5-7$ & 85.15 & 10 & 43 & \\
\hline $48 X-4,121-123$ & 410.75 & 6 & 54 & 40 & $14 X-2,19-21$ & 124.89 & 22 & 42 & \\
\hline $51 X-1,111-114$ & 435.91 & 5 & 51 & 44 & $15 X-C C, 28-30$ & 133.68 & 20 & 44 & \\
\hline $53 X-1,60-62$ & 449.70 & 4 & 62 & 34 & $21 \mathrm{X}-\mathrm{CC} .21-23$ & 192.01 & 22 & 51 & \\
\hline $56 \mathrm{X}-\mathrm{CC}, 18-19$ & 437.58 & 3 & 55 & 42 & $25 \mathrm{X}-1.21-23$ & 230.01 & 18 & 34 & \\
\hline $58 X-1,41-43$ & 493.21 & 10 & 43 & 47 & $30 X-2.15-17$ & 279.75 & 13 & 50 & \\
\hline $61 X-2,105-108$ & 524.25 & 9 & 44 & 47 & 31 X-CC. $15-17$ & 280.98 & $22(19)$ & $46(42)$ & $32(39)$ \\
\hline $64 X-1.69-70$ & 550.89 & 5 & 51 & 44 & $14 \mid-863 \mathrm{~B}-$ & & & & \\
\hline $67 X-2,70-72$ & $\begin{array}{l}581.40 \\
608,22\end{array}$ & $\begin{array}{l}8 \\
6\end{array}$ & $\begin{array}{l}47 \\
50\end{array}$ & 45 & $\begin{array}{r}141-86,3 \mathrm{~B}- \\
4 \mathrm{X}-3,31-33\end{array}$ & 329.66 & 19 & 39 & \\
\hline $10 \times-C C .2-4$ & 608.22 & 6 & 50 & 44 & $7 \mathrm{~N}-1,31-33$ & 355.21 & 22 & 44 & \\
\hline $141-861 \mathrm{C}$ & & & & & $10 R-1.15-17$ & 371.15 & 28 & 42 & \\
\hline $1 \mathrm{H}-1.12-15$ & 0.12 & 12 & 49 & 39 & $13 \mathrm{R}-1,12-14$ & 395.92 & $25(21)$ & $43(40)$ & $32(39)$ \\
\hline $3 \mathrm{H}-3,13-16$ & 15.63 & 5 & 53 & 42 & $15 R-2.76-79$ & 417.46 & 57 & 33 & \\
\hline $5 \mathrm{H}-3.62-64$ & 33.92 & 6 & 54 & 40 & 20R-CC, $4-6$ & 466.58 & 69 & 19 & \\
\hline $6 \mathrm{H}-2.94-96$ & 43.44 & 4 & 60 & 36 & $25 R-3,112-113$ & 515.82 & 64 & 18 & \\
\hline $10 \mathrm{H}-4.40-43$ & 75.90 & 3 & 53 & 44 & $31 \mathrm{R}-5,58-59$ & 575.18 & 60 & 21 & \\
\hline $13 X-1,39-44$ & 100.19 & 4 & 59 & 37 & $35 R-2,66-68$ & 609.86 & 58 & 23 & \\
\hline $15 X-3.55-60$ & 122.55 & 5 & 52 & 43 & $40 R-1.17-19$ & 656.07 & 56 & 25 & \\
\hline $18 \times-4.51-54$ & 153.51 & 5 & 58 & 37 & $42 \mathrm{R}-2, \mathrm{I}-3$ & 676.71 & $65(59)$ & $21(25)$ & $14(16)$ \\
\hline $25 X-1.89-92$ & 209.79 & 6 & 57 & 37 & $44 \mathrm{R}-4.104-108$ & 699.99 & $75(65)$ & $15(21)$ & $10(14)$ \\
\hline $29 X-1.97-99$ & 238.67 & 4 & 49 & 47 & $46 \mathrm{R}-1.38-42$ & 707.18 & $70(69)$ & $15(14)$ & $15(17)$ \\
\hline $33 X-1,107-110$ & 267.67 & 2 & 60 & $\begin{array}{l}38 \\
52\end{array}$ & $49 R-4.93-95$ & 738.63 & 58 & 22 & \\
\hline $36 X-1.52-55$ & 296.12 & 9 & 39 & 52 & & & & & \\
\hline
\end{tabular}

An unidentified amorphous phase is also present in all samples. The clay minerals identified in the bulk samples are chlorite and hydromica, which appear to be present in roughly equal amounts. From Core 141-863B-20R to the lowermost Core 49R (463.4-738.6 mbsf) the samples are dominated by smectites.

XRD analyses show that the clay fraction (Table 3 ) in sediments from Hole $863 \mathrm{~A}$ and from Hole $863 \mathrm{~B}$ (Cores $4 \mathrm{X}$ to $13 \mathrm{R}$ ) consists mainly of hydromica and chlorite. The remainder ( $4 \%$ to $28 \%)$ is represented by smectites. However, in sediments farther downhole, beginning with Core 141-863B-15R (417.4 mbsf), the clay fraction contains from $56 \%$ to $75 \%$ smectites. Cristobalite, amphibole (horn-

blende), quartz, feldspar, and an unidentified amorphous phase are present in the fine fraction of all samples in minor or trace amounts.

In the distribution of clay minerals from the sediments recovered at Site 863 we recognized three boundaries: between the intervals from 39 to $59 \mathrm{mbsf}, 85$ to $124 \mathrm{mbsf}$, and 395 to $417 \mathrm{mbsf}$. These boundaries coincide with the boundaries between Subunits IA and IB, Subunit IB and Subunits IIA + IIB, and Subunits IIA + IIB and Subunit IIC, respectively, but are incongruous with the age boundaries.

The differences in clay mineralogy between the lithologic Subunits IA through IIB and Subunit IIC recovered at Site 863 are well illustrated by a triangular diagram (Fig. 2), which demonstrates a clearly 


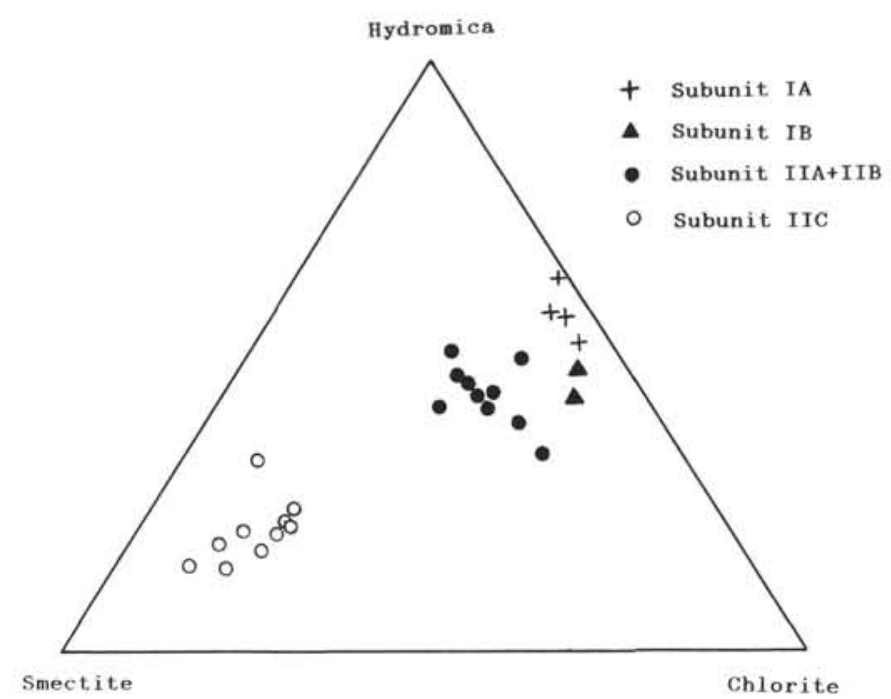

Figure 2. Relative abundance of clay minerals in the clay fraction of samples from Site 863 ,

increasing trend from smectite-poor Subunit IA through Subunit IIA + IIB to smectite-rich Subunit IIC. The latter field is apparently separated from the others by a wide gap, whereas other fields are close to each other, showing only a weak downhole-increasing trend in smectite. The major terrigenous clay mineral—chlorite and hydromica-persist in roughly equal proportions irrespectively of the smectite content, except for the uppermost Subunit IA, where hydromica predominates over chlorite. The high smectite content we detected in the Subunit IIC sediments is both in the clay fraction (less than $0.001 \mathrm{~mm}$ ) and in the fraction at $0.001-0.01 \mathrm{~mm}$ (Table 3 ). We believe that the sharp increase in smectite below $400 \mathrm{mbsf}$ is an effect of hydrothermal circulation in this lower part of the sedimentary sequence.

The morphology of the smectite, as demonstrated by a SEM microphotograph of Sample 141-863B-46R-1, 38-42 cm, is indicative of its secondary origin (Fig. 3). In this sample a secondary mineral, as determined by SEM (Fig. 4), may be zeolite. The chemical composition of the fraction less than $0.001 \mathrm{~mm}$ (Sample 141-863B$46 \mathrm{R}-1,38-42 \mathrm{~cm}$; Table 4) allows us to assign the smectite to the $\mathrm{Mg}-\mathrm{Fe}$ variety. We assume that $\mathrm{Fe}$ is mainly associated with smectite, because Fe oxyhydroxides are likely absent in the reduced sediments.

The chemical composition of the bulk sediments (Table 4) is fairly uniform, similar to that of common graywackes, including the sediments below $400 \mathrm{mbsf}$.

The coarse fraction mineralogy (Tables 1 and 2) of the Site 863 sediments does not show any significant differences from that described above for Sites 859 through 861 . The downhole distribution of heavy minerals is rather uniform, except for the lowermost part of the sequence below about $500 \mathrm{mbsf}$, where hornblende increases and epidote and clinopyroxene decrease possibly as a result of hydrothermal influence. In general, the mineral abundances vary irrespective of the lithologic subunits or sediment ages.

The light fraction (Table 2) is also similar in mineral composition to that at other sites. The downhole distribution of minerals, however, shows some significant deviations. The volcanic glass content is moderate in the upper part of the section down to $290 \mathrm{mbsf}$. Sample $141-863 \mathrm{~B}-10 \mathrm{R}-1,48-51 \mathrm{~cm},(371.48 \mathrm{mbsf})$, is apparently enriched in a vitric constituent, but below this level the glass content decreases sharply to $1 \%-3 \%$ and then to zero in the two lowermost samples from the hole. Quartz shows a reverse trend, and the lowermost two samples are enriched in quartz (up to $70 \%$ ). Note that the same samples are relatively enriched in hornblende and poor in clinopyroxene and that the lower part of the section is enriched in newly formed smectite.

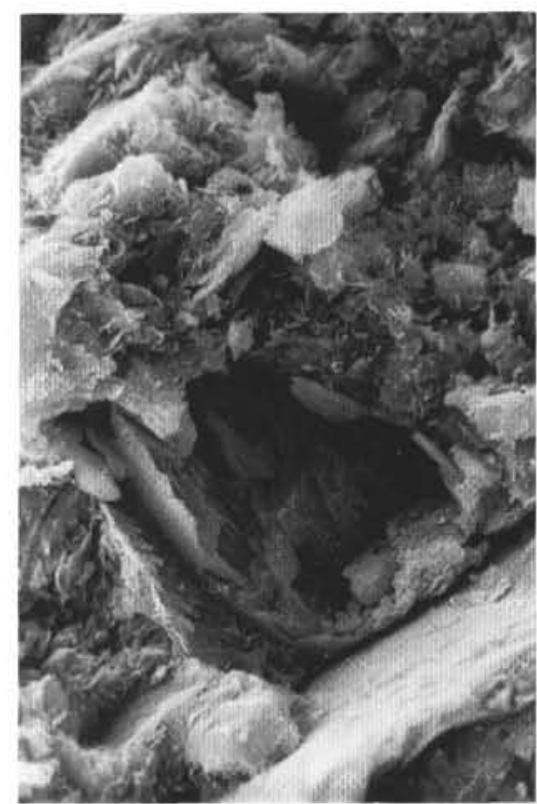

Figure 3. SEM micrograph of the secondary smectite; Sample 141-863B-46R$1,38-42 \mathrm{~cm}, \times 5000$.

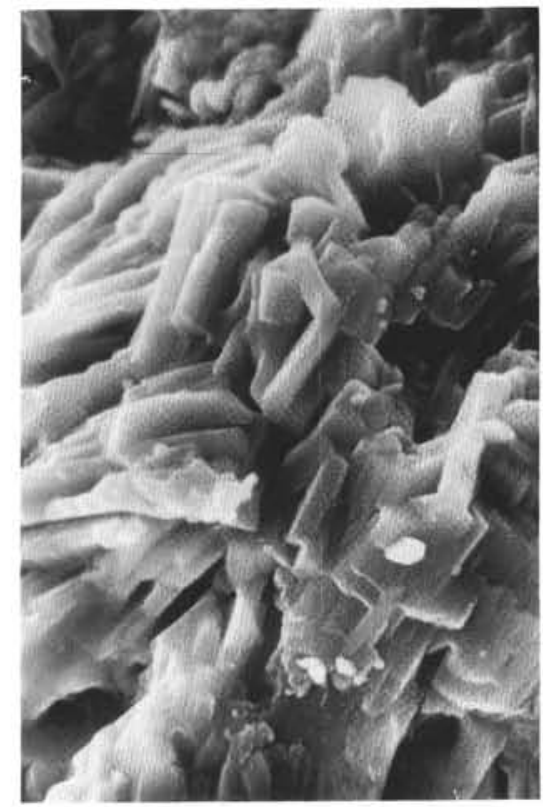

Figure 4. SEM micrograph of a secondary mineral (zeolite?); Sample 141$863 \mathrm{~B}-46 \mathrm{R}-1,38-42 \mathrm{~cm}, \times 5000$.

Thus, the data obtained at Site 863 show apparent changes in the mineralogy of sediments below about 400 mbsf which are expressed best by the sharp increase in smectite (Fig. 5). The higher smectite contents at 465-515 and about 700 mbsf approximately coincide with faulted and brecciated zones, which most likely favor hydrothermal circulation initiated from the active spreading center of the Chile Ridge subducted under the accretionary wedge.

\section{Mineralogy of Sediments Blanketing the Taitao Ridge (Site 862)}

The shipboard XRD mineralogy of bulk sediments (Samples 141$862 \mathrm{~A}-1 \mathrm{H}-3,118-120 \mathrm{~cm}$, and $141-862 \mathrm{~A}-2 \mathrm{H}-3,133-135 \mathrm{~cm}$, are 
Table 4. Chemical composition of sediments from Leg 141 Sites 862 and 863.

\begin{tabular}{lrrrrrrrrrr}
\hline Element & \multicolumn{1}{c}{1} & \multicolumn{1}{c}{2} & \multicolumn{1}{c}{3} & \multicolumn{1}{c}{4} & \multicolumn{1}{c}{5} & \multicolumn{1}{c}{6} & \multicolumn{1}{c}{7} & 8 & 9 & 10 \\
\hline $\mathrm{SiO}_{2}$ & 54.35 & 56.85 & 55.17 & 59.65 & 59.81 & 59.79 & 55.98 & 56.75 & 55.74 & 46.04 \\
$\mathrm{TiO}_{2}$ & 1.51 & 1.24 & 1.27 & 1.23 & 1.25 & 1.25 & 1.24 & 1.27 & 1.42 & 2.16 \\
$\mathrm{Al}_{2} \mathrm{O}_{3}$ & 16.90 & 14.67 & 16.07 & 14.64 & 14.47 & 13.97 & 14.91 & 14.03 & 14.70 & 13.59 \\
$\mathrm{Fe}_{2} \mathrm{O}_{3}$ & 3.29 & 4.73 & 4.65 & 3.49 & 4.85 & 4.20 & 3.77 & 4.28 & 4.38 & 13.36 \\
$\mathrm{FeO}$ & 3.93 & 3.48 & 3.17 & 2.83 & 2.44 & 3.33 & 4.40 & 3.50 & 3.79 & \\
$\mathrm{MnO}$ & 0.02 & 0.03 & 0.08 & 0.01 & 0.03 & 0.04 & 0.04 & 0.03 & 0.04 & 0.05 \\
$\mathrm{CaO}$ & 2.87 & 5.12 & 5.15 & 5.22 & 4.74 & 4.39 & 4.82 & 5.27 & 5.57 & 4.19 \\
$\mathrm{MgO}$ & 4.22 & 3.83 & 4.08 & 3.43 & 2.49 & 2.99 & 3.88 & 3.53 & 3.84 & 5.60 \\
$\mathrm{Na}_{2} \mathrm{O}$ & 5.45 & 3.96 & 3.88 & 3.80 & 3.65 & 3.72 & 3.80 & 3.17 & & \\
$\mathrm{~K}_{2} \mathrm{O}$ & 3.07 & 1.84 & 2.11 & 1.83 & 1.94 & 1.80 & 2.14 & 1.77 & & \\
$\mathrm{H}_{2} \mathrm{O}^{-}$ & 1.19 & 1.06 & 1.66 & 1.02 & 1.30 & 0.76 & 1.18 & 1.56 & 1.56 & \\
$\mathrm{H}_{2} \mathrm{O}^{+}$ & 3.39 & 3.59 & 2.92 & 2.64 & 2.56 & 3.39 & 3.72 & 3.37 & 3.56 & \\
$\mathrm{CO}_{2}$ & 0.00 & 0.00 & 0.00 & 0.00 & 0.60 & 0.00 & 0.00 & 1.15 & 0.75 & \\
$\mathrm{C}^{2}$ & 0.14 & 0.00 & 0.00 & 0.00 & 0.00 & 0.00 & 0.00 & 0.00 & 0.00 & \\
$\mathrm{P}_{2} \mathrm{O}_{6}$ & 0.09 & 0.11 & 0.16 & 0.03 & 0.01 & 0.01 & 0.04 & 0.05 & 0.18 & \\
$\mathrm{Total}^{2}$ & 100.42 & 100.51 & 100.37 & 99.82 & 100.14 & 99.64 & 99.92 & 99.73 & 95.53 & \\
$\mathrm{LOI}$ & 5.04 & 4.39 & 4.93 & 3.99 & 4.67 & 4.69 & 5.25 & 6.23 & 5.92 & \\
\hline
\end{tabular}

olive gray sediments from Subunit IB; Sample 141-862A-3H-4, $97-99 \mathrm{~cm}$ is the yellowish sediment of Subunit IC) showed that the dominant phase present in all of the samples is quartz, with less abundant feldspar. Hornblende is present in minor to trace amounts. An amorphous phase is also present in all samples (Behrmann, Lewis, Musgrave, et al., 1992). The obtained data are not indicative of any hydrothermal alteration in the yellowish sediments.

Clay minerals were studied by XRD in 23 samples from all three subunits, in the fractions less than $0.001 \mathrm{~mm}$ and $0.01-0.001 \mathrm{~mm}$ (Table 3). The distribution of clay minerals in sediments from Holes $862 \mathrm{~A}, 862 \mathrm{~B}$, and $862 \mathrm{C}$ does not show any changes that correlate with the transition from olive gray sediments (Subunits IA and IB) to yellowish sediments (Subunit IC), including the sample from beds immediately over basalt (Sample 141-862B-2X-CC, 30-33 cm, 21.57 mbsf). On a triangular diagram (Fig. 6) all of the studied samples are located in a single field, without significant variation. We conclude that hydrothermal circulation, if present at all, has not affected the clay mineral composition in Subunit IC sediments. This is confirmed also by comparison of the triangle diagram for Site 862 (Fig. 6) with that for Site 863, where the hydrothermal precipitation of smectite is apparent.

The chemical data from sediments from Site 862 (Table 4) show that they are almost uniform, except for $\mathrm{P}_{2} \mathrm{O}_{5}$ content.

The similarity of the coarse-fraction mineralogy of the sediments from Hole $862 \mathrm{~A}$ (Tables 1 and 2) to that at the other sites demonstrates a single terrigenous mineral province derived from the Andean source area. However, there are marked changes in the relative abundances of the transparent heavy minerals with depth. The uppermost sample $(0.21 \mathrm{mbsf})$ from Subunit IA is enriched in clinopyroxene (40\%) and relatively poor in hornblende $(6 \%)$. Clinopyroxene content decreases downhole to about $4 \%$ at the bottom of the sequence recovered, whereas hornblende increases to as high as $50 \%$ at $20.18 \mathrm{mbsf}$. The upper Pliocene yellowish layer less than $1 \mathrm{~m}$ thick (Subunit IC) above basaltic basement is characterized by downward increase in olivine (to $62 \%$ ) with a corresponding decrease in hornblende, epidote, clinopyroxene, and orthopyroxene.

Both the top and base of the sequence recovered are enriched in volcanic glass and plagioclase and poor in quartz and potassium feldspar, which indicates an increase in the volcaniclastic constituent, especially above basaltic basement. The high olivine content in the heavy fraction with increased volcanic glass and labradoritic plagioclase in the light fraction of Subunit IC sediments suggests a local source for the basaltic volcaniclastic material.

We have not found any evidence for hydrothermal alteration of the basal yellowish bed (Subunit IC) either in clay minerals or in the coarse fraction. The framboids of authigenic pyrite found in the basal sediments are obviously of common diagenetic origin, whereas the copper sulfides assumed by the shipboard visual description were not confirmed by our shorebased-laboratory study.

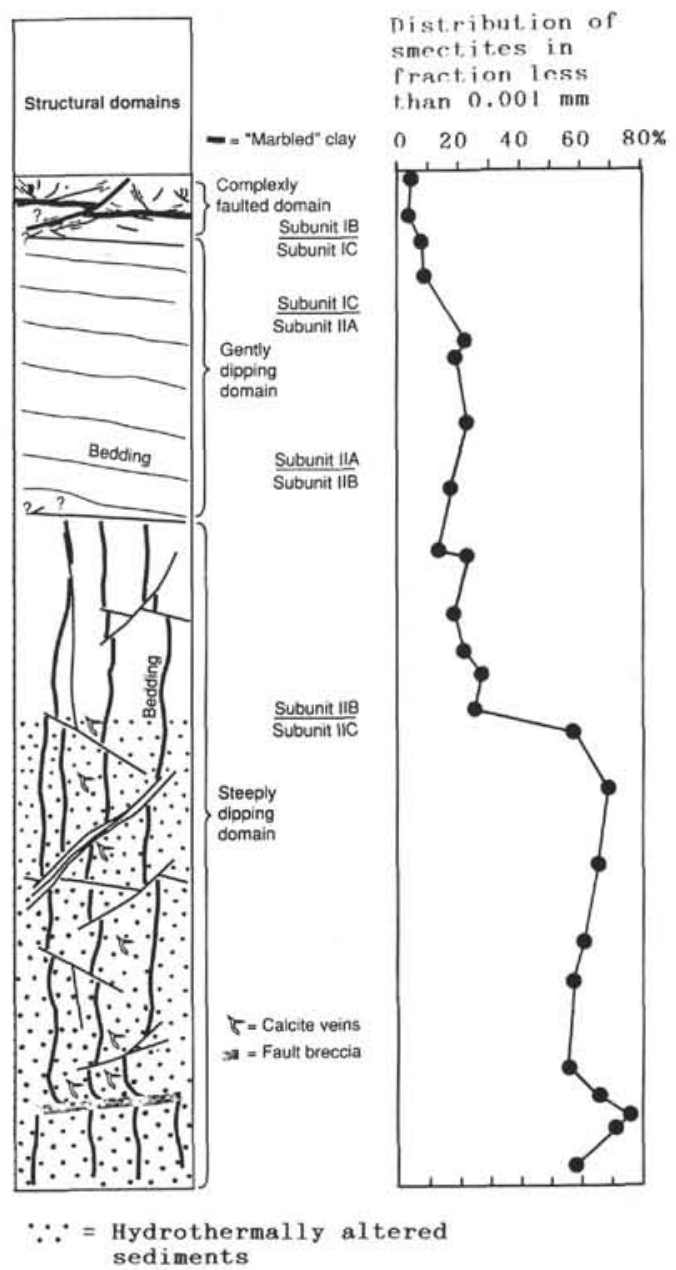

Figure 5. Hydrothermally altered sediments in Site 863.

\section{DISCUSSION}

The sedimentary sequences drilled during ODP Leg 141 at the Chilean Trench accretionary wedge near the Chile Triple Junction are Quaternary and Pliocene terrigenous turbidites and hemipelagites. The terrigenous sediments, which range from clay and silty clay to sand and rare gravel, have undergone strong post-depositional tectonic defor- 


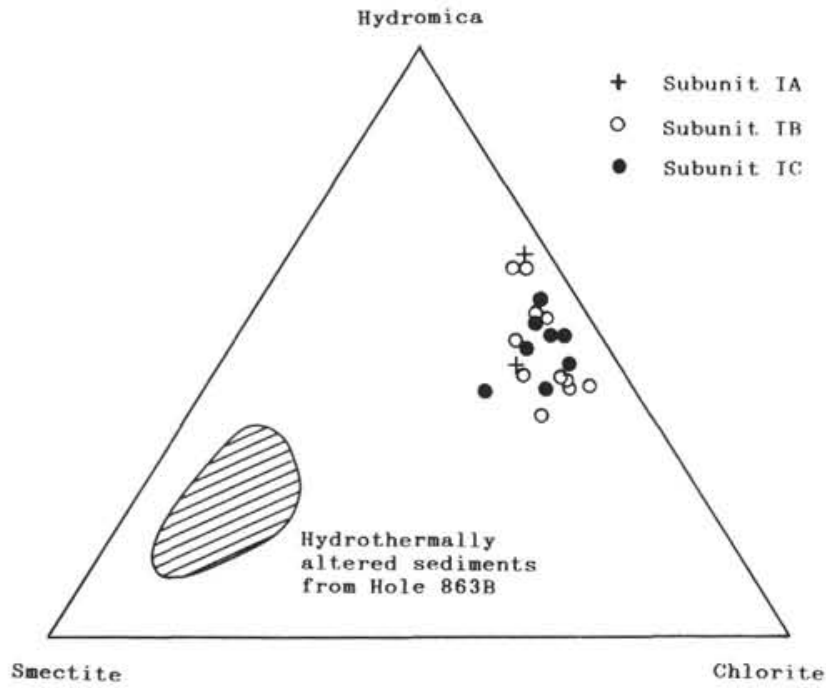

Figure 6. Relative abundance of clay minerals in the clay fraction of samples from Site 862.

mation during the accretion which includes underthrusting, faulting, and brecciation. The tectonic stresses resulted in induration of the young sediments and disturbed their primary bedding. However, our study does not reveal any essential changes in sediments mineralogy that may be attributed to the influence of the tectonic deformation. Our attempts to find mineralogical indicators of the involvement of the adjacent oceanic floor sedimentary cover in accretion also failed, owing to the uniform primary terrigenous mineralogy of the sediments.

We succeeded in achieving the second main objective of our study, to recognize the effects of hydrothermal circulation an the mineral composition of the sediments overriding the subducted active spreading ridge. Evidence was found for the hydrothermal alteration of the primary terrigenous mineralogy at Site 863 .

Thus, the following discussion focuses on our two main objectives: the primary terrigenous sedimentation and the hydrothermal alteration of sediments.

\section{Terrigenous Sedimentation}

Terrigenous sediments with only minor biogenic carbonates and silica was recovered at all of the holes drilled during Leg 141. Both the clay and coarse-fraction mineralogy of these sediments are generally uniform, irrespective of the location of the holes, water depth, depth below seafloor, lithologic units, and tectonic deformation and domains or lithification.

The coarse heavy fraction is characterized by dominant hornblende, the epidote group, and commonly less abundant clinopyroxene (Fig. 7). The minor components are orthopyroxene, tremolite-actinolite, olivine (sporadic), garnet, apatite, zircon, tourmaline, and sphene.

The light fraction is dominated by quartz, with plagioclase (Fig. 8) next in abundance, and potassium feldspar and mica in minor or trace amounts. Chlorite aggregates and chloritized rock fragments occur in both the heavy and light fractions. Volcanic glass is present in most samples, but varies widely in abundance, indicating a variable volcaniclastic contribution to the dominating terrigenous matrix.

The clinopyroxene-epidote-hornblende heavy mineral assemblage and plagioclase-quartz light fraction is widespread in recent sediments of the Pacific margins. Because this assemblage of terrigenous minerals is probably derived from the Mesozoic to Tertiary greenstonegreenschist formations that crop out in the surrounding Circum-Pacific orogenic belts, we named it the "greenstone" assemblage (Murdmaa et al., 1979; Murdmaa, 1987). The assemblage found in the Leg 141 sediments differs from that of the ocean floor (op. cit.) far from continental margins because it has higher amounts of quartz and accessory

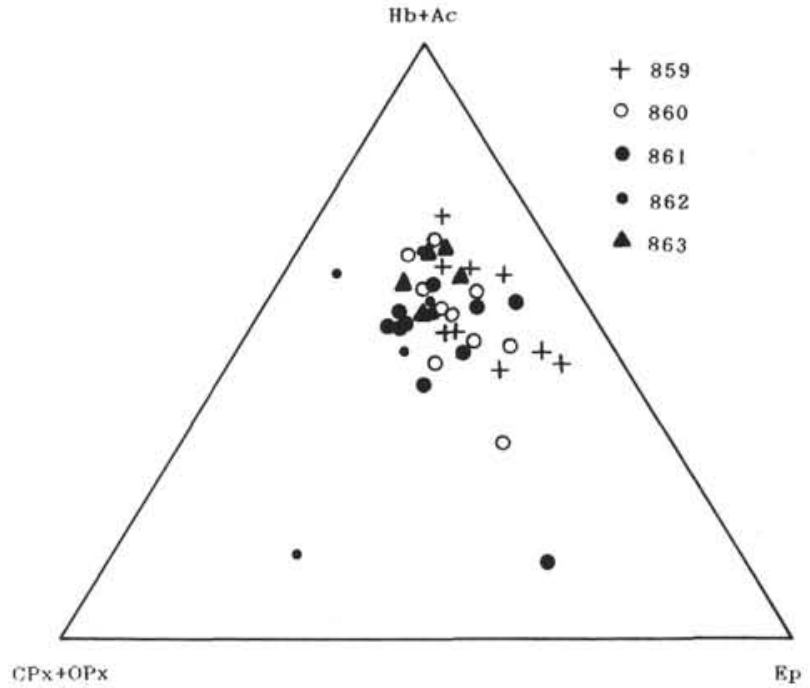

Figure 7. Relative abundance of heavy minerals (hornblende + actinolite epidote - clinopyroxenes + orthopyroxene) in the coarse fraction of sediments from sites of Leg 141.

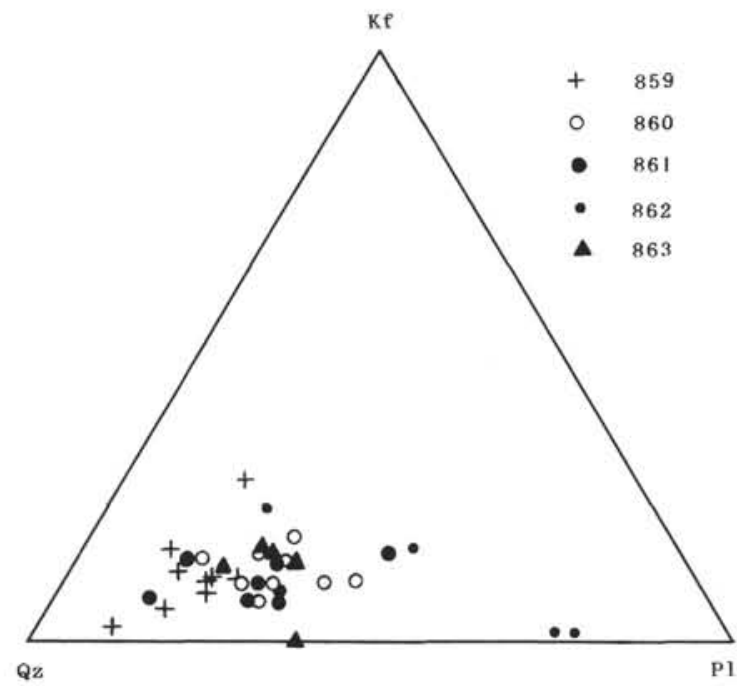

Figure 8. Relative abundance of light minerals (K-feldspar-plagioclase-quartz) in the coarse fraction of sediments from Leg 141 sites.

minerals, which indicates the proximity of the source area (obviously, the Andes). The sialic accessories, namely garnet, zircon, and tourmaline, as well as K-feldspar and mica, are most likely associated with some local source of outcropping sialic crystalline basement.

Superimposed on the background greenstone assemblage is a calc-alkaline ("andesitic") unaltered volcaniclastic assemblage, comprising a two-pyroxene (augite-hypersthene) heavy fraction and volcanic glass with andesine-labradorite in the light fraction (Murdmaa et al., 1979). This volcaniclastic admixture is probably derived from the Andean volcanic belt, but is most likely reworked rather than primary pyroclastic material. As shown above, the most prominent variations in the coarse-fraction mineralogy are produced by the relative proportion of the volcaniclastic constituent mixed with the "greenstone" assemblage.

The composition of clay minerals, which is dominated by chlorite and hydromica (Fig. 9), corresponds with the orogenic greenstone source suggested for the coarse fraction. The hydromica-chlorite clay-mineral assemblage with minor smectite was distinguished pre- 
viously in the recent sediments of the East Pacific margin near Chile (Griffin et al., 1968). The clay minerals are associated with the recent Circum-Pacific epidote-hornblende greenstone heavy mineral province (Murdmaa et al., 1979). Diagenetic processes have apparently not affected hydromica or chlorite. Variations in the abundances of these minerals, and probably that of smectite as well, is believed to reflect sedimentation processes and the primary composition of the terrigenous matter.

The monotonous supply of terrigenous matter from a single Andean source area to the continental trench slope sedimentation province is not accompanied by sorting of the minerals. The coarse fraction mineralogy in different lithofacial varieties of the sediments is similar; also, we did not find significant changes in mineralogy related to the grain size of the sediments. The relative proportions of both the coarsefraction and clay minerals along the downslope transect (Sites 861 through 859) does not show any regular changes. Only the basal beds of the sedimentary blanket over the Taitao Ridge contain volcanic minerals possibly derived from local submarine outcrops of the mafic igneous rocks.

Combining the mineralogical results with the shipboard descriptions of sediments and with micropaleontological data (benthic foraminifers) allow us to conclude that at least the recovered part of the accretionary wedge is built up of typical slope deposits, which accumulated primarily on the continental trench slope were supplied from a single source area. There is no evidence of the involvement of oceanic floor abyssal sediments in accretion during subduction. However, this does not exclude the possibility that this process occurred, as the mineral composition of hemipelagic sediments on the ocean floor margin is quite similar to that of the trench slope and we cannot distinguish differences between these two depositional settings using only mineralogical data.

\section{Hydrothermal Alteration}

An important deviation from the general trend can be seen in the smectite concentrations for Sample 141-859B-16R-4, 103-105 cm (Table 3). This sample with the highest abundance of smectite (34\%) in the section cored from the $260 \mathrm{mbsf}$ temperature anomaly (about $60^{\circ} \mathrm{C}$ at a depth of $250 \mathrm{mbsf}$ ) recorded by the WSTP and logging run. This suggests that the smectite anomaly at this level may be related to hydrothermal circulation. The same relation may apply to Sample 141-859B-28R-4, 75-77 cm (375 mbsf), which contains $32 \%$ smectite in the clay fraction.

As shown above, we found clear evidence of hydrothermal alteration of the primary terrigenous sediments at Site 863 below about 400 mbsf and to the bottom of drilling at Hole 863B. The hydrothermal effects are best demonstrated by extensive secondary smectite formation in the sediments. Other indications of hydrothermal circulation in the Subunit IIC sediments include the decrease of volcanic glass to zero (because of its smectitization), increase in quartz and amphibole, decrease in clinopyroxene, recrystallization of nannofossils, and presence of secondary minerals in veinlets and cavity fillings (Behrmann, Lewis, Musgrave, et al., 1992).

The shipboard interstitial-water data (Behrmann, Lewis, Musgrave et al., 1992) also suggest hydrothermal circulation in the Subunit IIC sediments. Below 400 mbsf, Mg, K, and perhaps Si are almost completely depleted and there is an increase in $\mathrm{Ca}, \mathrm{Li}, \mathrm{SO}_{4}, \mathrm{Sr}, \mathrm{F}$, and $\mathrm{B}$ and a steep pH increase at the same depth. Na concentration in interstitial water gradually decreases downhole from $400 \mathrm{mbsf}$. At about 400 mbsf is an abrupt change in sonic velocities and the organic geochemistry data show that propane and higher hydrocarbons appear below 400 mbsf.

The mineralogical data show that the sediments below $400 \mathrm{mbsf}$ are altered under low-temperature hydrothermal conditions, as suggested from the smectite facies (Kurnosov, 1986). The relatively low temperature of the hydrothermal mineralization is confirmed by wireline mea-

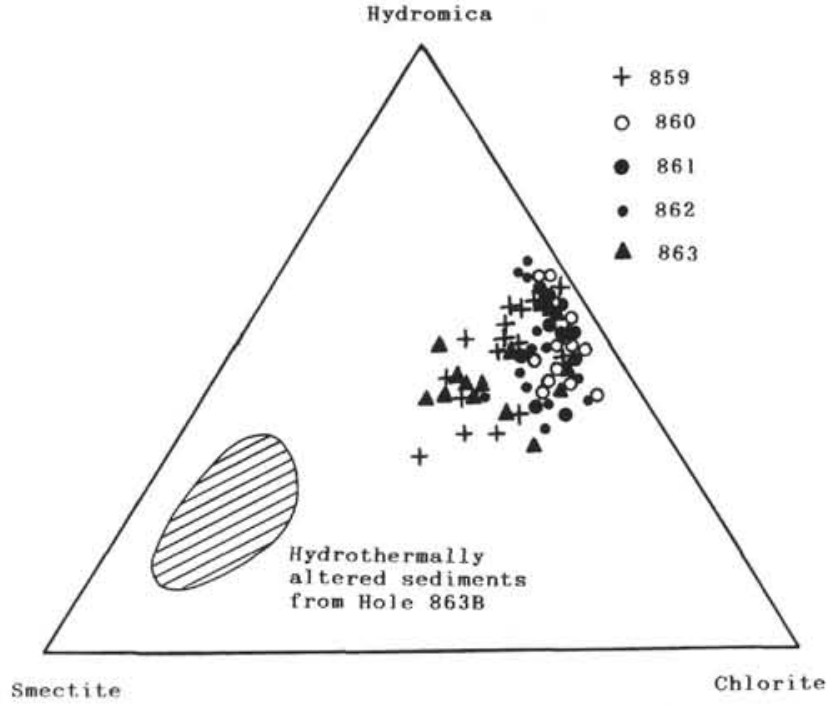

Figure 9. Relative abundance of clay minerals in the clay fraction of sediments from Leg 141 sites.

surements in the borehole: the temperature measured at the bottom of Hole $863 \mathrm{~B}$ is $65^{\circ} \mathrm{C}$ (Behrmann, Lewis, Musgrave, et al., 1992).

Below 400 mbsf at Site 863 a marginal low-temperature zone of hydrothermal alteration was possibly recovered. The borehole is east of the rift axis of the subducted Chile Ridge, and the bottom of Hole $863 \mathrm{~B}$ is considerably higher than the evaluated depth of the igneous basement surface. More strongly altered zones can be suggested to exist in the sediments directly overlying the ridge axis (Fig. 10). Such temperature-related hydrothermal alteration zonality was also studied in the Middle Valley of the Juan de Fuca Ridge (ODP Leg 139), where the terrigenous sediments are altered under much higher temperatures (about $250^{\circ} \mathrm{C}-300^{\circ} \mathrm{C}$ and more) on the level of greenschist facies, and the clay minerals were formed mainly with chloritic structure (Davis, Mottl, Fisher, et al., 1992; Kurnosov et al., in press).

Therefore, the results show that the subduction of an active spreading ridge beneath an accretionary wedge leads not only to extensive deformation of the trench slope sedimentary strata, but also to hydrothermal alteration of the sediments. The hydrothermal circulation in the Chilean accretionary wedge is most likely created by high heat flow from the subducted spreading ridge. Interstitial waters of the accretionary wedge sediments are heated from below and circulate as hydrothermal fluids preferentially in the more permeable tectonized zones, where the primary sedimentary structure is strongly deformed by faulting and brecciation. The shipboard observations provide evidence that the hydrothermal alteration of the sediments does not correspond to any structural break or unconformity, and is thus apparently postdeformational.

The strongest hydrothermal effects occur possibly in the basal layers of the sedimentary sequence just above the subducted spreading ridge, where the temperature is thought to be highest. However, hydrothermal circulation in the newly formed oceanic crust probably ceases soon after ridge subduction beneath the accretionary wedge, as direct contact with the oceanic bottom waters no longer exists and the fluid supply is restricted. Hence, hydrothermal circulation in the accretionary wedge over the subducted spreading ridge may not be affected by leaching of the basaltic crust, as is the case of a midoceanic ridge open to the bottom waters.

Subduction of the spreading ridge produces a "hydrothermal trace" in the accretionary wedge. The trace can possibly be found south of the Leg 141 sites, where the Chile Ridge was subducted earlier. The trace can be applied as an indicator of the subduction trajectory for fossil subducted ridges of ancient Pacific-type continental margins. 


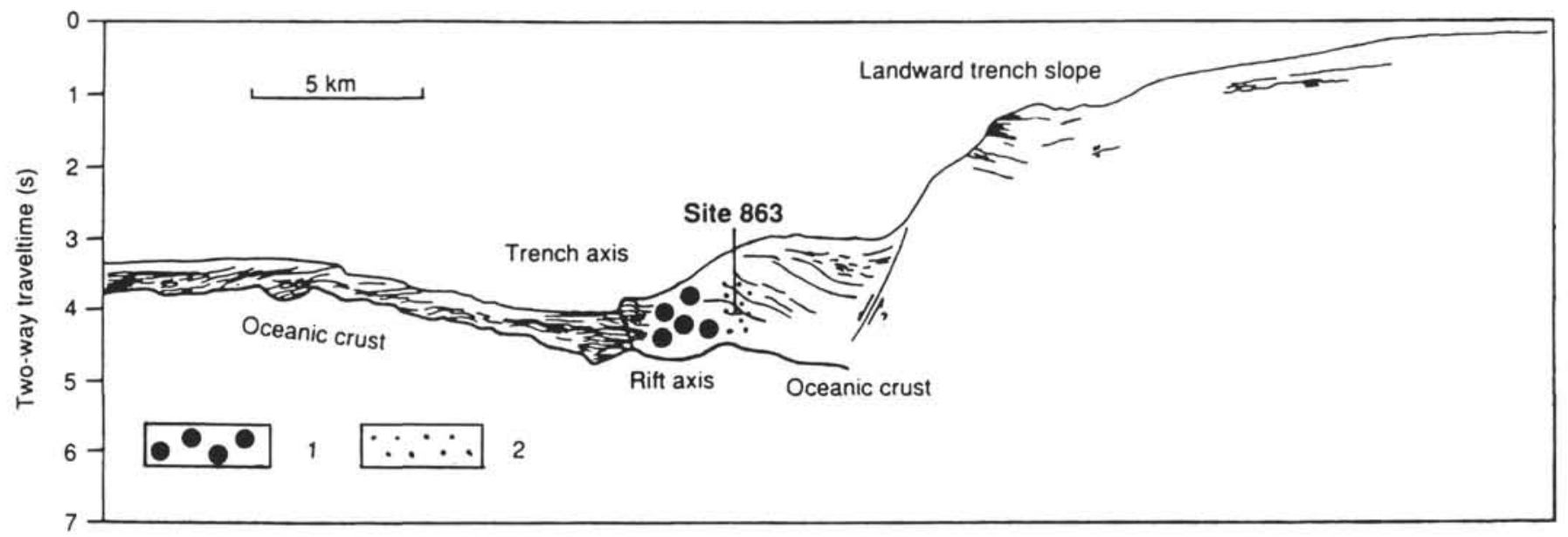

Figure 10. Hydrothermal alteration of sediments above the subducted ridge axis. $1=$ maximum hypothetical alteration of sediments above the ridge axis. $2=$ observed alteration of sediments under low-temperature hydrothermal circulation near the ridge axis.

The Taitao Ridge sediment blanket was also thought to be affected by hydrothermal alteration. However, our mineralogical and geochemical study of Samples 141-862B-2X-CC, 30-33 cm, from just above the basalt, and $141-862 \mathrm{C}-1 \mathrm{~W}-1,18-21 \mathrm{~cm}$, which is intercalated with the basalt, did not show any evidence of hydrothermal mineralization. The hydrothermal nature of the pyrite concretions assumed aboard ship for Core 141-862C-1W-1 has not been confirmed by our shorebased-laboratory investigation. We believe that the concretions are either of diagenetic origin or redeposited. Nor has our detailed study confirmed the assumed presence of bornite, chalcopyrite, and covelline among the sulfides in Sample 141-862C-1W$1,18-21 \mathrm{~cm}$.

\section{CONCLUSIONS}

The mineral composition of terrigenous sediments cored from the Chile Trench continental slope within the Chile Triple Junction region is common for American Pacific continental margin mineralogical provinces. The mineral assemblage found in the accretionary wedge sedimentary sequences drilled during Leg 141 is derived from the adjacent Andean orogenic source area, which also supplies terrigenous matter for hemipelagic sedimentation on the Pacific floor margin. Therefore, the terrigenous mineralogy cannot be used as a criterion to distinguish between the autochtonous slope deposits and ocean floor sediments possibly accreted into the wedge during subduction.

Hydrothermal alteration of the sediments drilled at Site 863 in the post-collision accretionary wedge evidence subduction of the continuously active Chile spreading ridge. Hence, the subduction of the spreading ridge can be traced by hydrothermal effects in the overlying accreted sedimentary sequences.

\section{ACKNOWLEDGMENTS}

We thank the reviewers for useful critical remarks; A. Sokolova, E. Pokrovskaya, A. Salyn, N. Ryapolova, N. Zavadskaya, T. Kuzmina, V.
Kazakova, and A. Rudakova for analytical work, and V. Vasiljeva for help in data processing.

\section{REFERENCES}

Behrmann, J.H., Lewis, S.D., Musgrave, R.J., et al., 1992. Proc. ODP, Init. Repts., 141: College Station, TX (Ocean Drilling Program).

Biscaye, P.E., 1965. Mineralogy and sedimentation of recent deep-sea clays in the Atlantic Ocean and adjacent seas and oceans. Geol. Soc. Am. Bull., 76:803-832.

Davis, E.E., Mottl, M.J., Fisher, A.T., et al., 1992. Proc. ODP, Init. Repts., 139: College Station, TX (Ocean Drilling Program).

Griffin, J.J., Windom, H., and Goldberg, E.D., 1968. The distribution of clay minerals in the World Ocean. Deep-Sea Res, Part A, 15:433-459.

Kurnosov, V., Murdmaa, I., Rosanova, T., Kashintzev, G., Eroshchev-Shak, V., and Krasnov, S., in press. Mineralogy of hydrothermally altered sediments and igneous rocks at Sites 855-858, Middle Valley, Juan de Fuca Ridge, Leg 139. In Davis, E.E., Mottl, M.J., Fisher, A.T., Slack, J.F., et al., Proc. ODP, Sci. Results, 139: College Station, TX (Ocean Drilling Program).

Kurnosov, V.B., 1986. Hydrothermal Alterations of Basalts in the Pacific Ocean and Metal-bearing Deposits, Using Data of Deep-sea Drilling: Moscow (Izd. Nauka).

Murdmaa, I.O., 1987. Facies of Oceans: Moscow (Nauka).

Murdmaa, I.O., Serova, V.V., Lisitsyn, A.P., and Emelyanov, E.M., 1979. Terrigeneous and volcanigenic clastic minerals of sand- and silt-size fractions. In Bezrukov, P.L. (Ed.), Ocean Geology: Sedimentation and Magmatism of Ocean: Moscow (Nauka), 180-197.

Abbreviations for names of organizations and publications in ODP reference lists follow
the style given in Chemical Abstracts Service Source Index (published by American Chemical Society).

Date of initial receipt: 16 August 1993

Date of acceptance: 21 January 1994

Ms 141SR-002 